\title{
Comparative Analysis of Lighting Elements' Effects on Electric System
}

\author{
Sait Dursun ${ }^{1} \mathbb{D}$, Umit Kemalettin Terzi ${ }^{2} \mathbb{D}$, Onur Akar ${ }^{3+} \mathbb{D}$, Temel Sonmezocak ${ }^{4}(\mathbb{D}$ \\ ${ }^{1}$ Department of Electrical-Electronics Engineering, Marmara University, MSc Student, Istanbul, Turkey, (e-mail: saitdursun@marmara.edu.tr). \\ ${ }^{2}$ Department of Electrical-Electronics Engineering, Marmara University, Istanbul, Turkey, (e-mail: terzi@marmara.edu.tr). \\ ${ }^{3 *}$ Department of Electrical and Energy, Istanbul Gedik University, Istanbul, Turkey, (e-mail: onur.akar@ gedik.edu.tr). \\ ${ }^{4}$ Department of Electrical and Energy, Istanbul Haliç University, Istanbul, Turkey, (e-mail: temelsonmezocak@halic.edu.tr).
}

\section{ARTICLE INFO}

Received: Aug., 11. 2021

Revised: Sep., 15. 2021

Accepted: Oct., 17. 2021

Keywords:

Quality of power

Lighting elements

Harmonics

Crest factor

Inrush Current

Flicker effect

Corresponding author: Onur AKAR

ISSN: 2536-5010 | e-ISSN: 2536-5134

\section{ABSTRACT}

Due to the increase of demand for energy requirement, and the decrease of energy sources day by day, it is being understood that it is required to efficiently use the energy sources in order to ensure the balance of demand for electric energy. The lighting elements use about $1 / 5$ of the electric energy produced in our country. Especially while selecting the lamps with high energy efficiency, it is important to consider the circumstances which may create negativities such as harmonics, power factor, crest factor, inrush current, and flicker effect in terms of quality of power. Moreover, impurity which may occur in the network affects the other devices negatively. In this study, the quality of power of lighting elements of more than one type was examined in detail. In the experiments, technical analyses were performed by the use of 13 different lighting elements extensively used in our country at site, factory, and domestic environments, and they were evaluated in terms of their positive and negative effects on the network.

\section{INTRODUCTION}

Please The lighting elements have significant place in electricity production. The use of electricity for lighting is $40 \%$ in the field of industry, $20 \%$ at sales stores, and $40 \%$ at office buildings. As understood by the rates given, lighting has great share on energy consumption. Significant energy saving may be ensured by the efficiency of light sources used for lighting, and by the use of sources with the lowest damage on electricity system [1]. About $20-25 \%$ of the electrical energy is used in lighting sector in Turkey. It is expressed that $56 \%$ of the energy consumed for lighting is being used in the buildings. When considered from this point of view, the requirement for the effective and efficient use of lighting energy arises [2]. Today, $35 \%$ of the electrical energy is consumed at lodgings, and in service sector. This data is about $40 \%$ of the world average. $60 \%$ of the electrical energy is consumed at lodgings and in service sector for only lighting [3, 4].

The increase of requirement for lighting day by day causes its share to be high in energy consumption, and the increase of use of energy transmission lines. For this reason, in order to attain uninterrupted lighting, the efficient use of sources providing lighting should be considered. It is required to well separate the efficiency, and saving. Turning off one of the two lighting lamps is saving, and the use of lighting elements which consume the energy more technologically and less is an example of efficiency $[5,6]$. In order to provide quality electrical energy for the lighting system, it is required to consider some criteria such as the requirement of having the voltage and frequency steady, of having the power factor close to 1 , of having the phase voltages balanced, and of having the amount of harmonics in voltage within specific limit values [7]. The harmonics arising in the networks to which lamps with glow filament are connected causes increase of voltage, and this causes the excessive heating of filaments. This condition decreases the lifetime of filaments by $50 \%$. The main reason of this is the excessive temperature arising in the filaments connected to harmonics. And single layer harmonics significantly affect the fluorescent lamps. The components of harmonics arising from voltage cause loss of iron in the ballasts of fluorescent lamps along with noise. In case of a comparison between fluorescent with magnetic ballast, and fluorescent with electronic ballast, it is observed that fluorescents with electronic ballast add 2-3 times more harmonics on electric system. Moreover, they are significant 3rd sources of harmonics in lamps of discharge group, and the harmonics 
being 3 and products of 3 complete their cycle from the neutral line. This circumstance causes the excessive heating of neutral line, and additionally the increase of voltage between neutral and ground. For this reason, it causes occurrence of failures in electronic devices connected to the system [8-10]. Another type of lamp is LED. The harmonic effects of LED laps on electric system are less compared to fluorescent lamps, and more compared to other lamp groups. In terms of efficiency, it is observed that LED lamps are $80 \%$ more efficient compared to fluorescent lamps and lamps with glow filament, and that fluorescent lamps are $84 \%$ more efficient compared to lamps with glow filament. In addition, the drawing of high current by the LED lamps at initial run, and the formation of harmonic effect by them are their undesired features [11]. Another issue drawing attention in lighting is the flicker effect. Flicker effect arises in an electric system in which the number of lamps with glow filament and fluorescent lamps are high, and in which voltage fluctuations occur by the effect of harmonics. This condition also negatively affects the health of eyes [12].

\section{MATERIAL AND METHOD}

\subsection{Quality of power relationship of lighting elements}

The harmonics are significant components for the quality of power. For a clean and environment friendly energy, it is required to have voltage amplitude, voltage surges, and flicker effects, and to have the wave in sinus form, to preserve the frequency, and to have the phases balanced, and to preserve the voltage amplitude. But as the lighting elements draw non-linear current from the network, they generate harmonics, and this circumstance significantly affects the quality of power $[13,14]$. Total Harmonic Distortion (THD) indicates the ratio between the RMS values of harmonics and main components of current and voltage. The total harmonic distortion of voltage is calculated as in Equation (1) [15].

$$
T H D_{V}=\frac{\sqrt{\sum_{n=2}^{\infty} V_{n}^{2}}}{V_{1}}=\frac{\sqrt{+V_{2}^{2}+V_{3}^{2}+V_{4}^{2}+\cdots . . V_{2}^{2}}}{V_{1}}
$$

And the total harmonic distortion of current is calculated as in Equation (2).

$$
T H D_{I}=\frac{\sqrt{\sum_{n=2}^{\infty} I_{n}^{2}}}{I_{1}}=\frac{\sqrt{+I_{2}^{2}+I_{3}^{2}+I_{4}^{2}+\cdots . . I_{2}^{2}}}{I_{1}}
$$

The ratio between the peak value (Im, or Um) and RMS value of non-sinusoidal current or voltage is called the crest factor. Thus, the crest factor (CF) if wave not covering harmonic components is $\sqrt{2}$ and it is indicated in Equation (3).

$$
C F=\frac{\text { Peak Value of Ware }}{\text { Effevtive Valueo of Wave }}
$$

\subsection{The relationship between harmonics and lighting}

The element with highest effect in the network is the $3^{\text {rd }}$ harmonic with a frequency of $150 \mathrm{~Hz}$. The $3^{\text {rd }}$ harmonics generally arise from non-linear loads such as lighting elements and computer which are single phase loads. Under normal conditions, there is no current in the neutral conductor in networks where three phases are balances. But in case of presence of $3^{\text {rd }}$ harmonic component in the network, current is observed on the neutral line. The amount of harmonics occurring in the phase conductor of the network with lighting element of discharge group is about $30 \%$ of the phase current. For instance, as seen in Figure 1, a current three times the amount of harmonics arising from a single phase current is able to pass on neutral line to which three phase currents are connected, and thus heating is able to occur on the neutral line $[10,16]$. For this reason, as per the international EMC directive, the currents caused by the $3^{\text {rd }}$ harmonic should be considered while making the crosssection calculation of neutral conductor at a project facility. If $3^{\text {rd }}$ harmonic filter will be present on the system of project facility, the calculation of currents to be caused by the $3^{\text {rd }}$ harmonic, and the design of neutral conductor at high values will not be required [9].
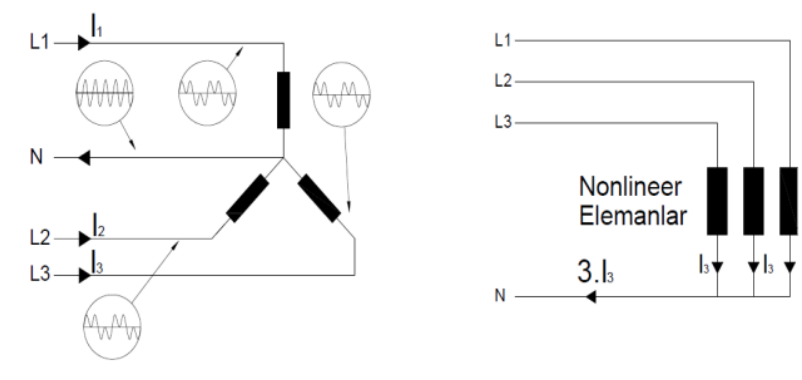

Figure 1. $3^{\text {rd }}$ harmonic currents passing from neutral line

In cases when the $3^{\text {rd }}$ harmonic currents arising at neutral pass from primary coils of the transformer, $3^{\text {rd }}$ harmonic occurs on transformer coils. As seen in Figure 2, the passage of arising $3^{\text {rd }}$ harmonic again to the network from the transformer may be prevented by making delta connection on transformer coils. But this condition causes the increase of losses at the transformer $[16,17]$.
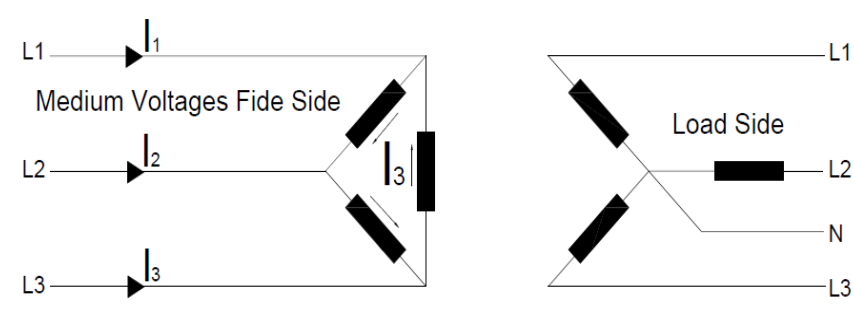

Figure 2. Prevention of harmonics on transformer coils

The increase of sources generating harmonics causes undesired circumstances on the electrical network. In order to prevent such circumstances, the standard institutions of various countries have required bringing in some limitations against the harmonics [18]. Such standards may be applied on electronic and electrical equipment whose input current is up to $16 \mathrm{~A}$ (including $16 \mathrm{~A}$ ) per phase, and which are considered to be connected to low voltage networks. The equipment specified for lighting equipment cover the following.

- Lighting devices and lamps,

- Lighting part of multi-functional equipment that light as one of the primary functions,

- Independent ballasts, and independent glow lamp transformers for discharge lamps,

- Ultraviolet (UV), and infrared (IR) radiation equipment,

- Lit advertising sign boards,

- Attenuators used in lamps except glow lamps 
The above are equipped in 4 different manners for limitation of harmonic current They are categorized in 4 classes named in Classes A, B, C, and D given in Table 1 .

TABLE I

CLASSIFICATION OF ELECTRIC DEVICES

\begin{tabular}{|c|c|}
\hline CLASS & FEATURE \\
\hline Class A & $\begin{array}{ll}- & \text { Balanced } 3 \text { phase devices } \\
\text { - } & \text { Household appliances except Class D } \\
\text { - } & \text { Devices except portable ones } \\
\text { - } & \text { Dimmers of lamps with glow filament } \\
\text { - } & \text { Audio devices } \\
\text { - } & \text { All devices except Classes B, C, and D }\end{array}$ \\
\hline Class B & $\begin{array}{ll}\text { - } & \text { Portable devices } \\
\text { - } & \text { Non-professional arc devices }\end{array}$ \\
\hline Class C & - $\quad$ Lighting devices \\
\hline Class D & $\begin{array}{l}\text { - Computers, and computer monitors } \\
\text { - Television receivers } \\
\text { Note: The devices' power level should be between } 75 \mathrm{~W} \\
\text { and } 600 \mathrm{~W} \text {. }\end{array}$ \\
\hline
\end{tabular}

According to TS EN 61000-3-2 device classification, the lighting devices are addressed in Class $\mathrm{C}$. The limit values determined for Class $\mathrm{C}$ equipment are as follows:

\section{a) Active input power $\geq \mathbf{2 5} \mathrm{W}$}

The currents for lighting equipment with an input power greater than $25 \mathrm{~W}$ are like the relative limit values specified in Table 2. They shouldn't exceed these limit values.

\section{b) Filter Active Power $\leq 25 \mathrm{~W}$}

The lighting equipment with gas discharge, with an active input power equal to or smaller than $25 \mathrm{~W}$, should conform to one of the following terms:

- Harmonic currents shouldn't exceed limit value relevant to power on Column 2 in Table 3.

- The $3^{\text {rd }}$ harmonic current, expressed as a percentage of the main component current, shouldn't exceed $86 \%$, and the $5^{\text {th }}$ shouldn't exceed $61 \%$. If the discharge lighting equipment has a light attenuator device, the measurement should only be performed in case of full load [19].

TABLE 2

HARMONIC LIMIT VALUES FOR CLASS C EQUIPMENT

Harmonic degree

(h)

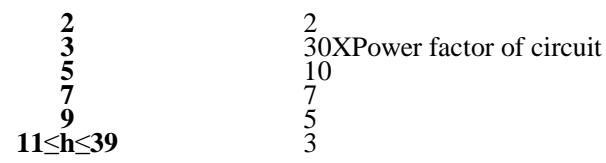

TABLE 3

HARMONIC LIMIT VALUES FOR CLASS C EQUIPMENT
Harmonic degree

(h)

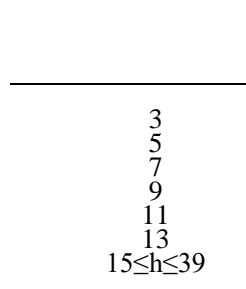

$\mathbf{P} \leq 600 \mathrm{~W}$

Largest harmonic current allowed per Watt $(\mathrm{mA} / \mathrm{W})$

3.4
1.9
1.0
0.5
0.35
0.296
$3.85 / \mathrm{h}$

$\mathrm{P} \geq 600 \mathrm{~W}$

Largest harmonic current allowed

(A)

\subsection{Quality of power relationship of lamps with glow filament}

The lamps with glow filament don't draw reactive power for the network as ohmic load, and their power factor is equal to 1 . For this reason, they don't generate harmonics, and their active and visible powers are equal. In a study performed, the total harmonic effect of lamp with glow filament was measured as $1.2 \%$. This is much below the standards [14]. The lamps with glow filament are devices affected from network voltage fluctuations. The resistance of the lamp varies depending on the temperature. During initial run, the glow lamp may draw inrush current 20-30 times more than the nominal current due to coldness of its resistance. For this reason, it is required for the fuse, used for protection, to be delay action fuse [20].

\subsection{Quality of power relationship of lamps of discharge group}

They fluorescent, mercury, and sodium vapor lamps operating with discharge principle. They operate with the principle of discharge of gas being present in their tubes. These lamps operating with discharge principle have a non-linear current voltage form, and for this reason they are source of $3^{\text {rd }}$ harmonics. The magnetic ballasts connected to discharge group lamps are also significant sources of harmonics. Recently, electronic type ballasts are being used instead of old type magnetic ballasts. It has become possible to prevent the harmonics by placing harmonic filter in such ballasts [15].

\subsection{Quality of power relationship of LED lamps}

As all types of lighting elements are sources of harmonics, it was determined that LED lamps, rapidly entering the electric market recently, have significant distorting effect on quality of power of electrical network. In a study performed, the Total Harmonic Distortion (TDH) of LED lamp group for the network was measured as $159 \%$, and this is much above the standards. For this reason, it is obligatory to apply a filter on LED lighting groups [13, 21-23].

\section{RESULTS AND DISCUSSION}

In this section, analyses of quality of power and harmonics were performed by forming real-time experimental mechanism on 13 different lighting elements used in lighting sector. The effect of each lighting element on the network was examined, and their superiorities or negative aspects in terms of type of light source and actuator constructs were compared. The light sources, used in the experiment, consisted of lamps with glow filament, discharge group lamps, and LED lamps. 


\subsection{Quality of power relationship of $L E D$ lamps}

In the experiment, voltage, current drawn from the system, power factor, changes in \% THD, inrush currents, and crest factors were examined for lamp with glow filament. In Figure 3 , the testing mechanism of this lamp is indicated

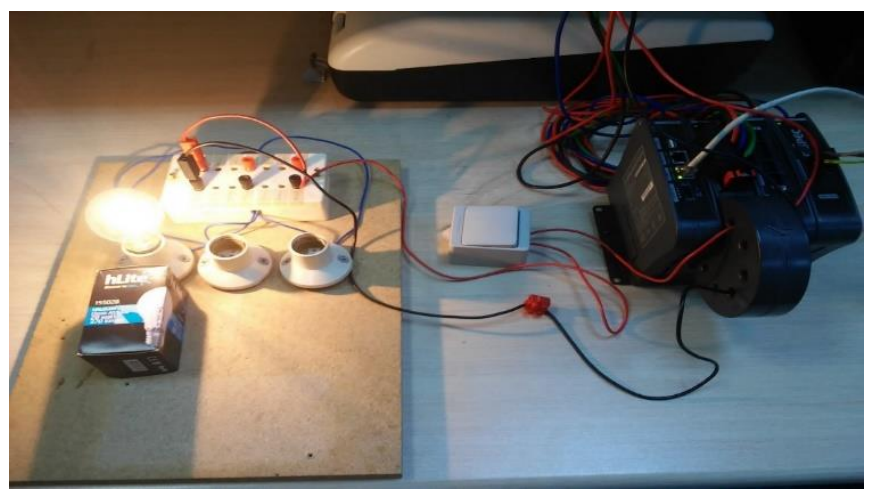

Figure 3. Experiment mechanism for lamp with glow filament

In Figure 4, when the graphs obtained from the analyzer for lamp with glow filament are examined, it is observed that it is steady ohmic load in terms of quality of power, and thus it consumes only active load from the network.

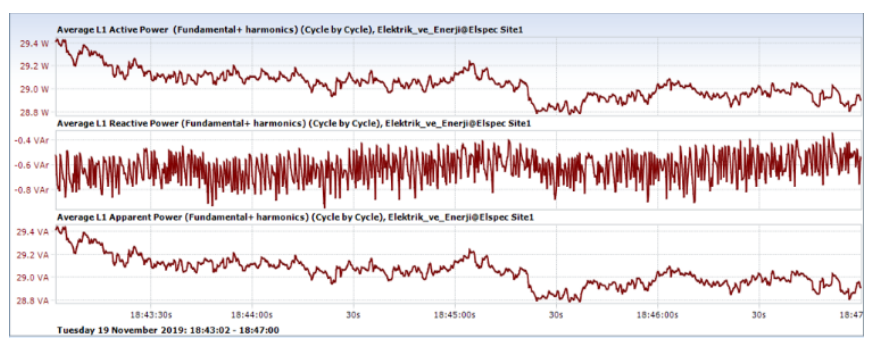

Figure 4. The lamp's active power (basic + harmonic), reactive power (basic + harmonic), visible power (basic + harmonic) values in the measurement process

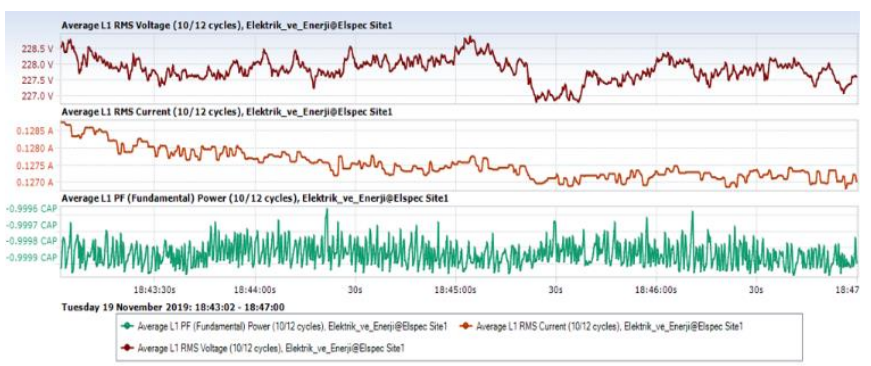

Figure 5. RMS voltage, RMS current, and replacement power coefficient $(\operatorname{Cos} \varphi)$ values in the measurement process

As observed in Figure 4, a lamp of $30 \mathrm{~W}$ consumed a reactive power below the value of 1 VAr thus, as observed in Figure 5, $\mathrm{PF}$ value was measured as 0.99. Moreover, significant variations in current and voltages based on time were observed for the lamp with glow filament. When we consider this lamp in terms of inrush currents during switching arising at start and stop, by the examination of test records obtained from the analyzer in a period of $30 \mathrm{sec}$., it was observed that it is drawing an instant current 10 times the approximate load current of the network. The results of experiment are shown in Figure 6.

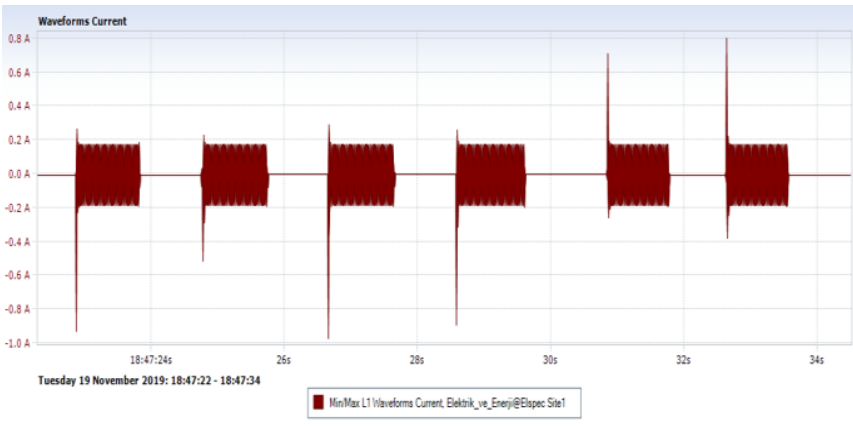

Figure 6. Inrush currents at six switching moments in the process of switching at $30 \mathrm{sec}$.

The crest factor value of glow lamps is having a value very close to $\sqrt{2}$. These values Vary between 1.440 Amperes and 1.480 Amperes as observed in Figure 7.

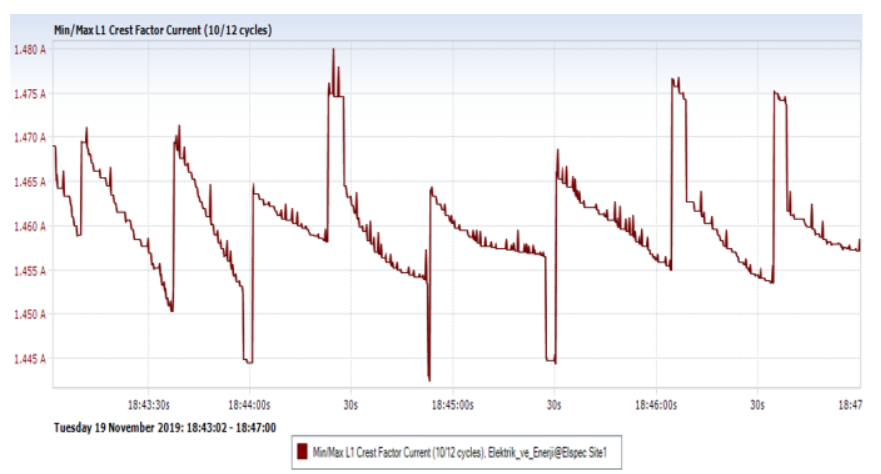

Figure 7. Crest factor of the current passing from the lamp during the measurement
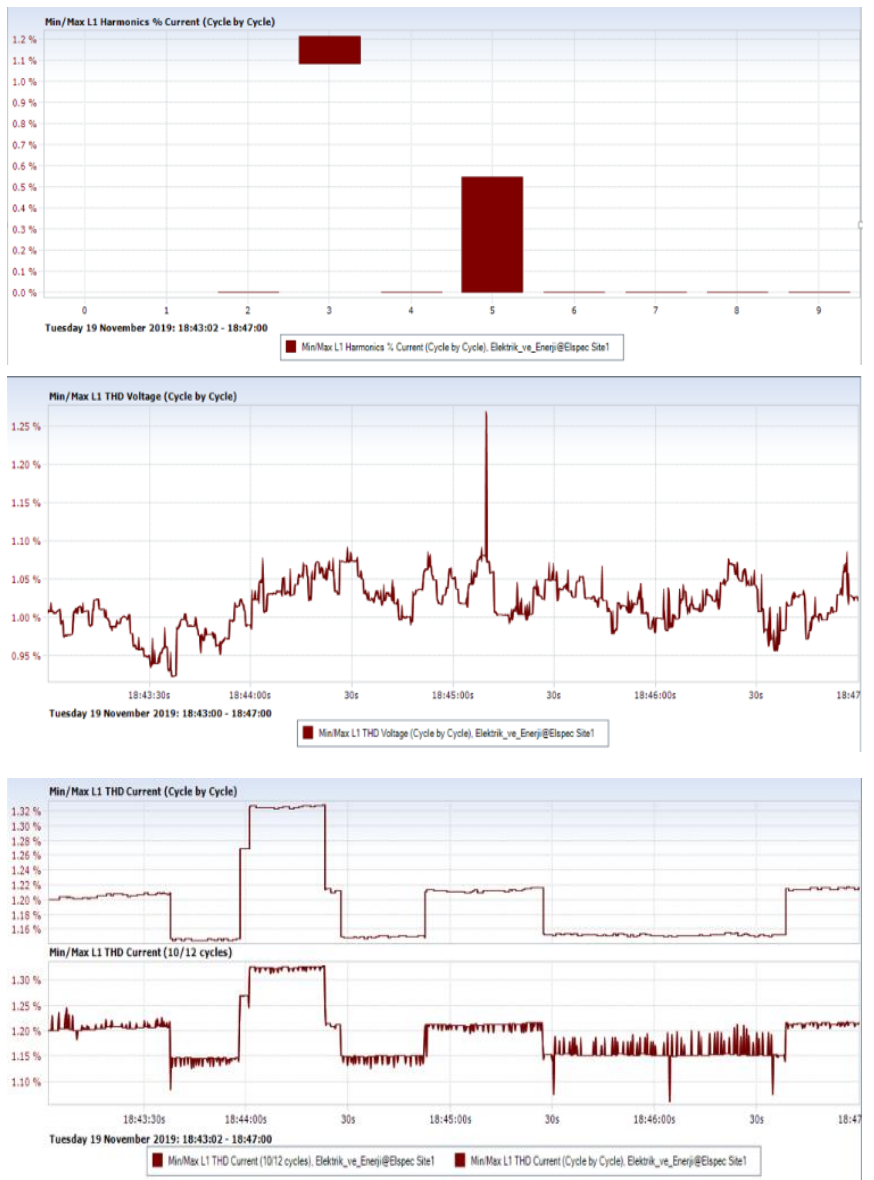

Figure 8. Current and voltage harmonics of glow lamps 
When considered in terms of (\%) THD, along with the harmonic values of voltage and current were at the level of $1 \%$ THD, it was understood by the examination of graphs in Figure 8 that they were very low, and that they were arising from $3^{\text {rd }}$ harmonic. Because glow lamps are ohmic linear loads.

\subsection{Results of network analysis obtained for discharge type lamps}

They are fluorescent, mercury, and sodium vapor lamps operating with discharge principle. They operate with the principle of discharge of gas being present in their tubes. In this study, these lamps were examined under two groups as being low pressure and high pressure.

\subsubsection{Low Pressure Fluorescent Type Lamps}

In the experiment, the analyses of different types of fluorescent lamps frequently used at lodgings, factories and stores were performed. The testing mechanisms are indicated in Figure 9. In the experiment, voltage and current drawn from the system, power factor, changes in Total Harmonic Distortion (\%THD), inrush currents, and crest factors were examined for these lamps.

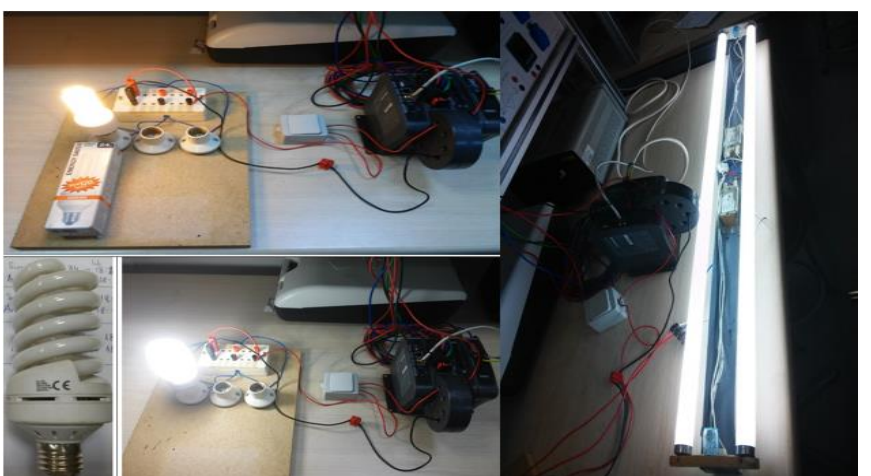

Figure 9. Testing mechanisms for fluorescent lamps

Fluorescent lamps also consume power reactively from the network. Reactive power amounts are different as per the igniter ballast mechanism used by the lamp. Thus, the lamp gets capacitive values above $\cos \varphi=0.90$ in electronic type igniter systems, and its power factor $(\mathrm{PF})=0.6$ is not being equal in terms of capacity. The main reason of this is that it grounds on other waves that actually exist while measuring the power factor value, in other words the harmonics arising in the system decrease the PF value of the system as reactive components, and the PF value draws away from the $\cos \varphi$ value in the system. In Figure 10, this difference is specifically indicated.

As also shown in the above figure, even if the $\cos \varphi$ value of electronic igniter compact fluorescent lamps is high, their PF values are actually low and have capacitive characteristics. The main reason of this is that this load exhibits a non-linear behavior, and that the wave form of current distorts in the system depending on the sinusoidal voltage applied, in other words current harmonics are present. The presence of harmonics sis clearly indicated on graphs in Figures 11, 12, and 13 .

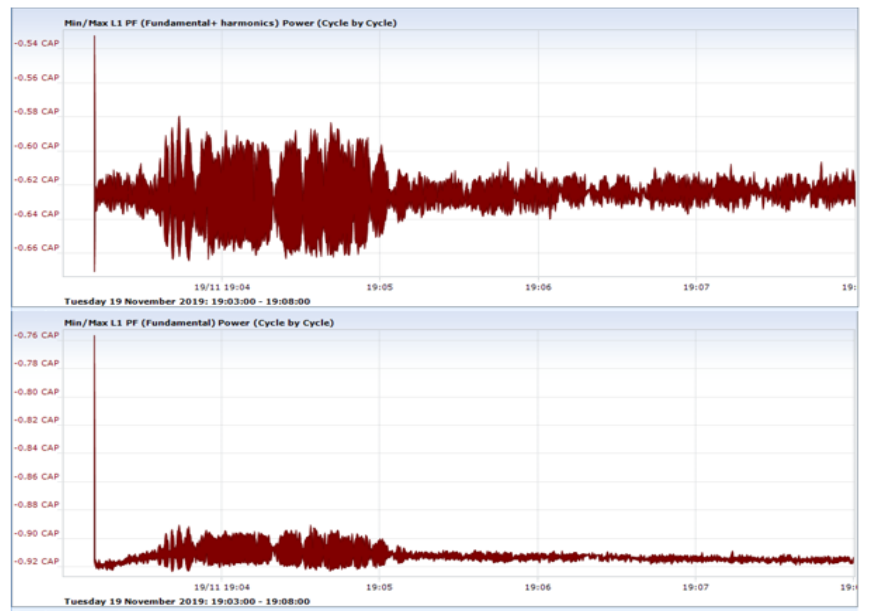

Figure 10. $\operatorname{Cos} \varphi$ and $P F$ relationship of electronic igniter $32 \mathrm{~W}$ compact fluorescent lamp

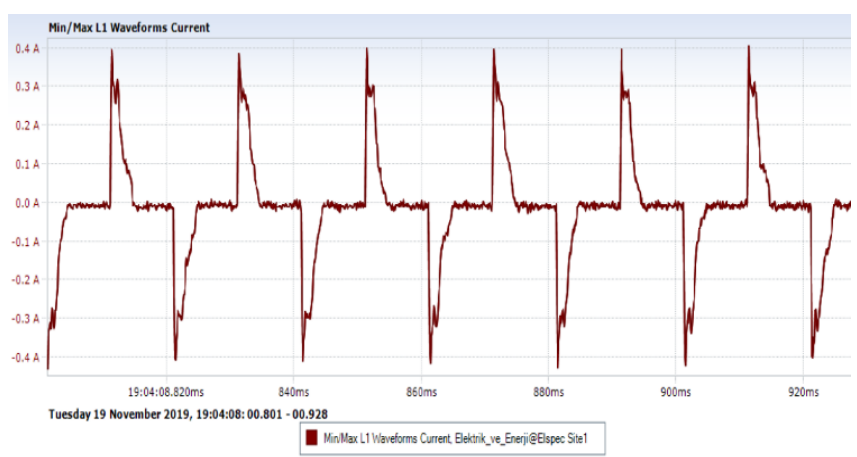

Figure 11. Waveform of current passing from the $32 \mathrm{~W}$ compact lamp

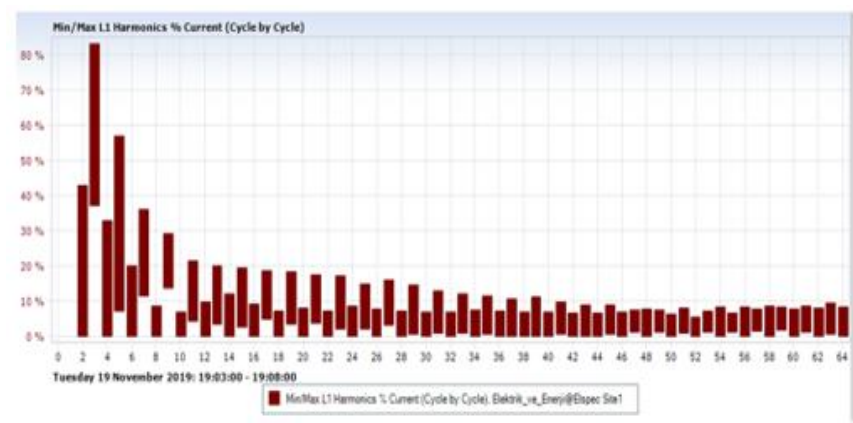

during the measurement

Figure 12. Harmonic current spectrum in L1 phase of electronic $32 \mathrm{~W}$ compact lamp (\% rate)

As seen in Figure 12, it is observed that the $3^{\text {rd }}$ harmonic component in this lamp is dominant as above $80 \%$. In this type of lamps, respectively $5^{\text {th }}$ and $7^{\text {th }}$ harmonic components are also present at high rates following $3^{\text {rd }}$ harmonic.

Total harmonic distortion of this lamp was measured as $100 \%$ in a time interval of $30 \mathrm{sec}$. as seen in Figure 13.

But this circumstance is different in fluorescent lamps with magnetic ballast. In this type of lamps, $\cos \varphi$ and $P F$ values are equal, and they indicate 0.45 inductive characteristic. Along with the reactive power component is high in the network, it lacks in harmonic values as the $\cos \varphi$ and PF values are nearly the same.

In Figure 14, the current waveform obtained as the result of measurement of a $\mathrm{T}_{5}$ type fluorescent lamp of $2 \times 36 \mathrm{~W}$. As observed in Figure 14, waveform of current is very close to sinusoidal form. In other words, the harmonic values of current are at low rates below 10\%. This is also shown in Figure 15. 


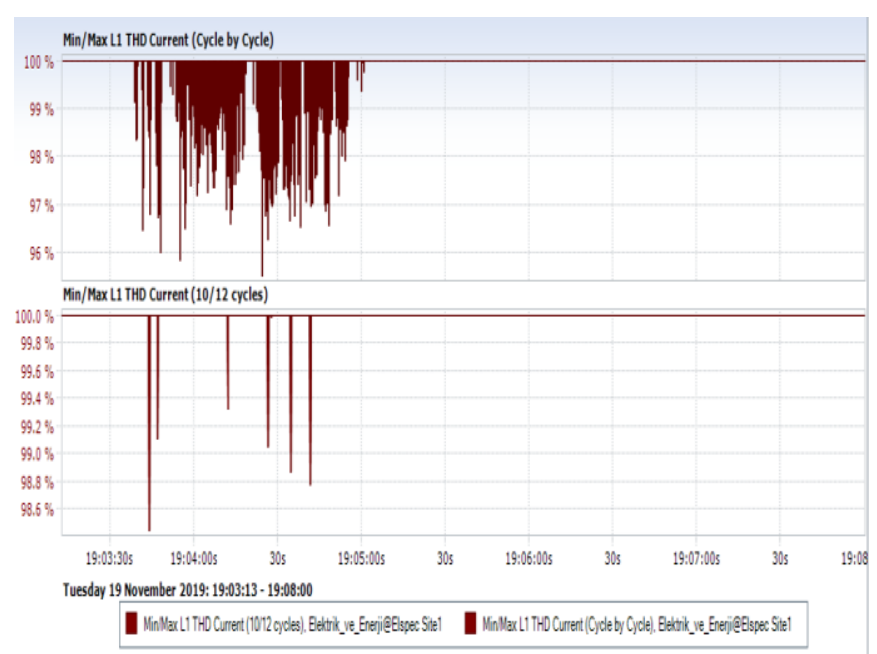

Figure 13. Change of THD (Total Harmonic Distortion) value of $\mathrm{L}_{1}$ phase current during measurement of $31 \mathrm{~W}$ compact lamp

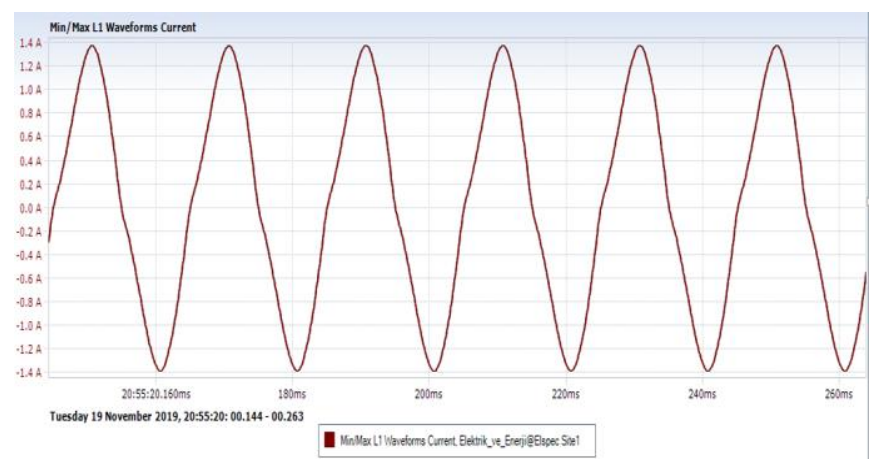

Figure 14. Waveform of current in $\mathbf{T}_{5}$ type fluorescent lamp with magnetic ballast during measurement

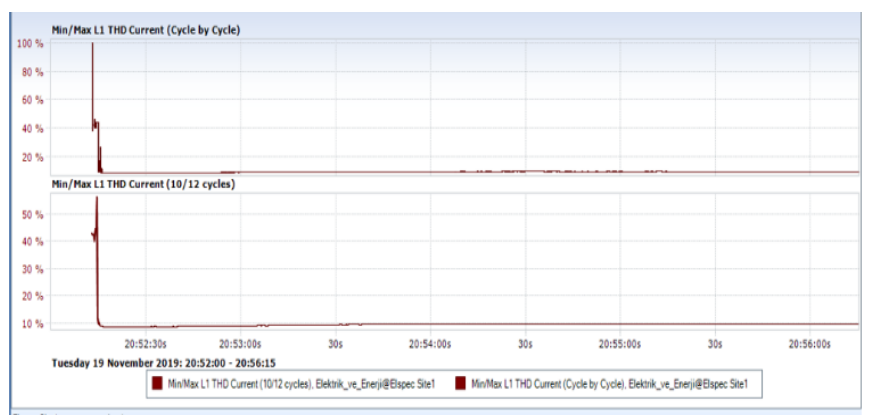

Figure 15. Change of THD (Total Harmonic Distortion) value of $\mathbf{L}_{\mathbf{1}}$ phase current during $32 \mathrm{~W}$ measurement

In the above figure, the THD values reached peak values at instant temporary state behavior only during initial switching, and then decreases below the level of $10 \%$ at a constant rate in the permanent state.

In the examinations performed, it was found that the fluorescent type lamps with electronic ballast have non-linear load characteristic by containing electrostatic switching elements. Moreover, they contain harmonics in the network. In this sense, it was observed by the analyses that the values of crest factor and inrush current are high compared to lamps with magnetic ballast. This difference is clearly observed by graphs in Figures 16 and 17.

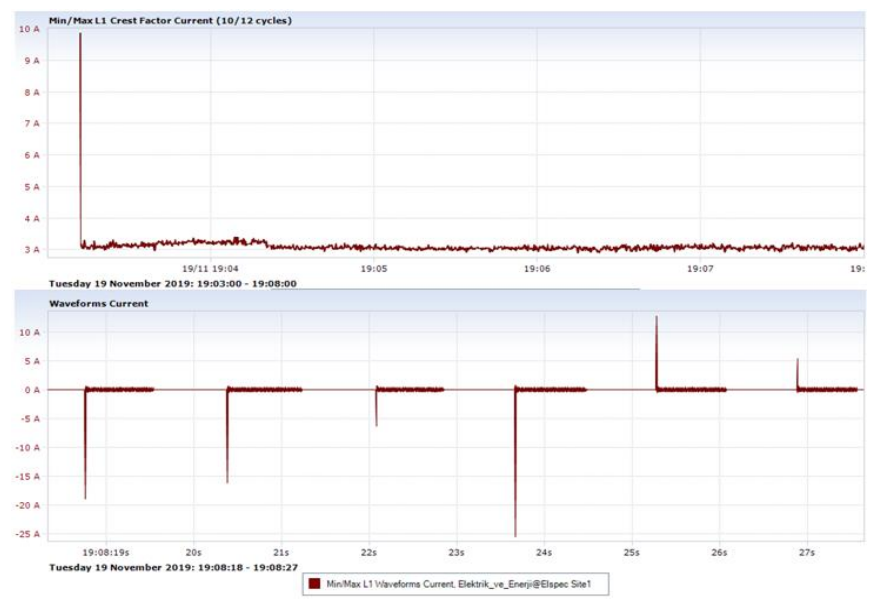

Figure 16. Change of inrush current and crest factor obtained for $2 \times 36 \mathrm{~W}$ for fluorescent lamp with magnetic ballast

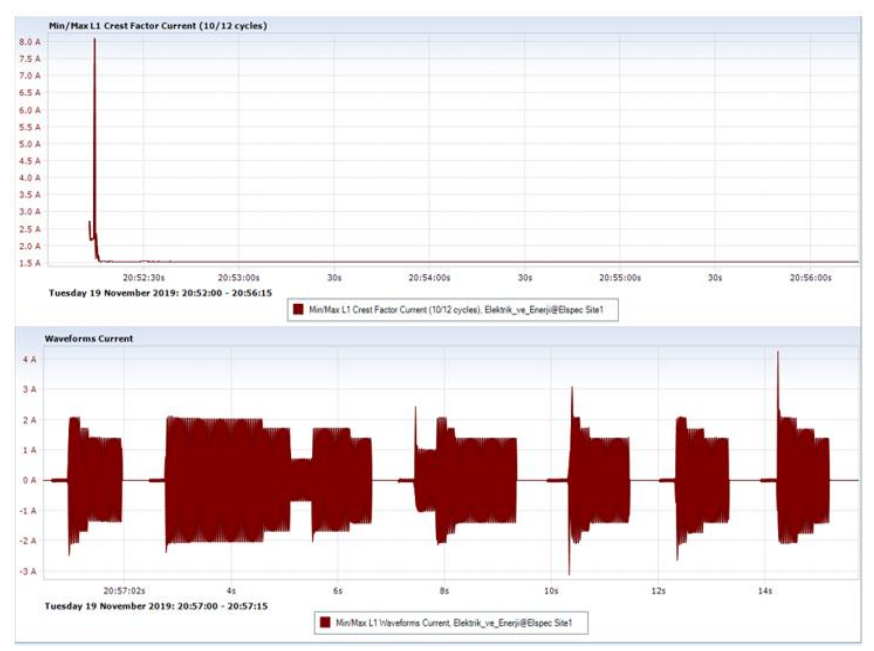

Figure 17. Change of inrush current and crest factor obtained for $2 \times 36 \mathrm{~W}$ for fluorescent lamp with magnetic ballast

\subsubsection{High pressure mercury and sodium vapor lamps}

High pressure lamps are generally used at lighting sites, and for lighting streets and roads. These lamps have external ballast unit as in the low pressure fluorescent lamps. Thus, these lamps were examined as mercury and sodium vapor ones along with their control gears. Lamp control gears used in the experiments are shown in Figure 18.

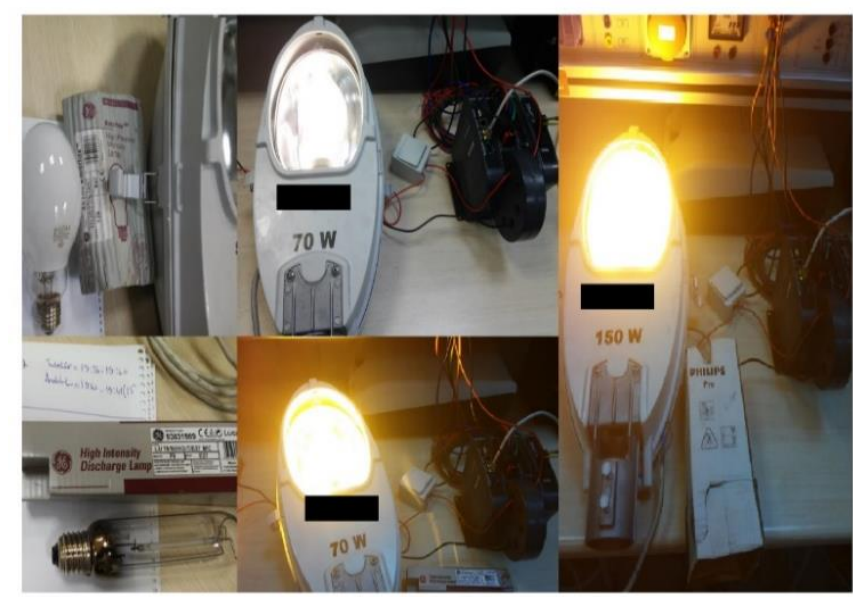

Figure 18. Testing Mechanisms of High Pressure Sodium Vapor and Mercury Vapor Lamps 
In the experiment, high pressure lamps of different powers, and different types were used. These lamps show same characteristics with each other. Especially the inrush currents of these lamps are at high levels compared to low pressure lamps. In Figures 19 and 20, the inrush current graphs of two different lamp types with the same power $(150 \mathrm{~W})$ obtained by performing on-off a specific intervals are indicated. As seen in these figures, the power and current values that these types of lamps demand from the system are high compared to other lamps. It is observed that the inrush currents also have high values. The inrush current values of both of these lamps were measured as the same as 75.5 A. These lamps have non-linear characteristics. In the experiments performed, it was observed that they form current harmonics in the connected network.

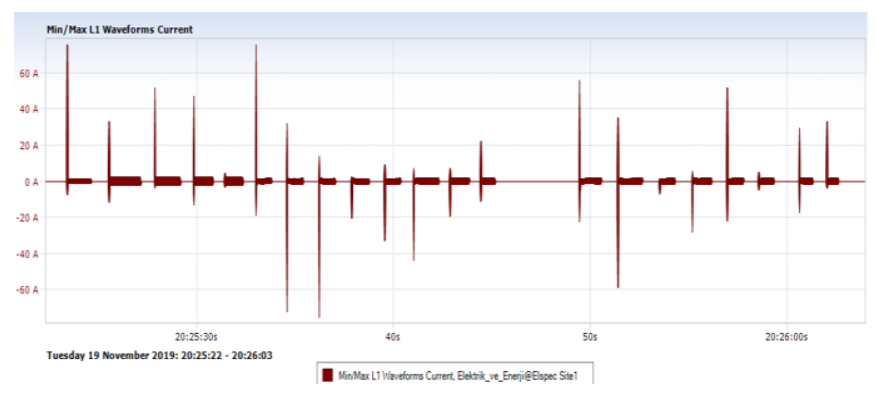

Figure 19. Temporal change of inrush currents obtained during one minute switching of $150 \mathrm{~W}$ mercury vapor lamp

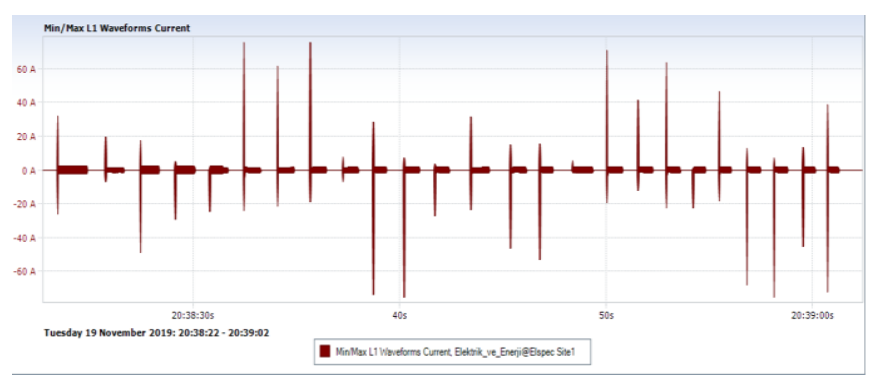

Figure 20. Temporal change of inrush currents obtained during one minute switching of $150 \mathrm{~W}$ sodium vapor lamp

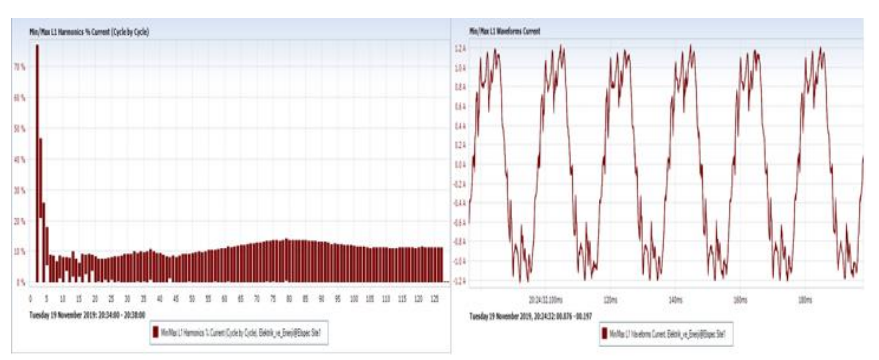

Figure 21. Current harmonics (\% THD), and current waveform of $150 \mathrm{~W}$ mercury vapor lamp
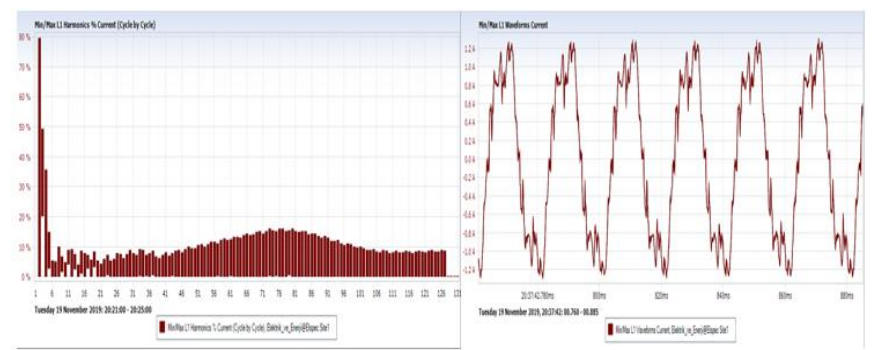

Figure 22. Current harmonics (\% THD), and current waveform of $150 \mathrm{~W}$ sodium vapor lamp
By the above Figure 21 and 22, it is observed that the sodium and mercury vapor lamps are subjected to distorting in the current waveforms due to presence of non-linear load in the network, and especially due to the dominance of $3^{\text {rd }}$ harmonics. This distortion is at the level of 20-30\% THD.

Current and voltage fluctuations were not observed on the network. But during heating of the lamp, the values of current and voltage are able to vary. PF value got inductive values up to 0.9 with an average of 0.56 along with heating as starting from a minimum value of 0.30 . In Figure 23, the changes of current, voltage and PF are shown.

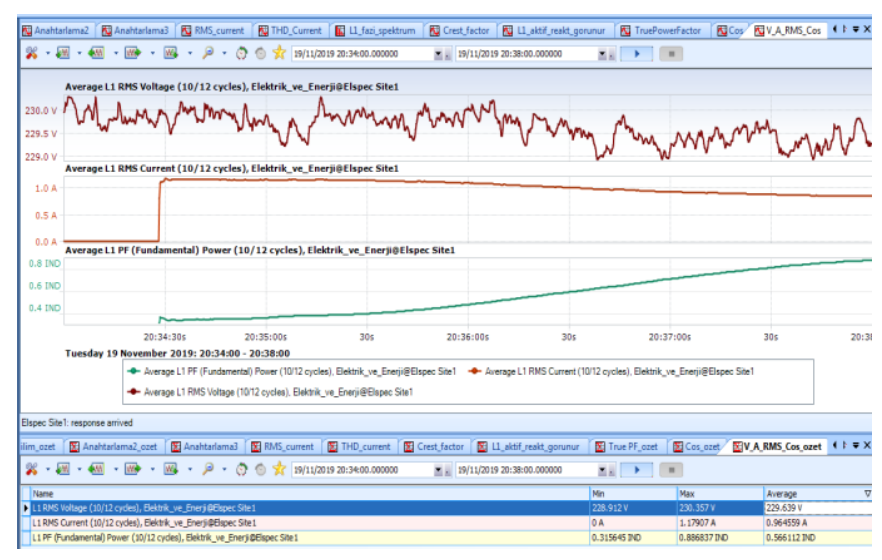

Figure 23. RMS voltage, RMS current, and replacement PF values during measurement

\subsection{Results of network analysis obtained for LED lamps}

In this study, experimental measurements were performed on 5 different LED loads, and the quality of power of each load was examined. These loads are ones that are becoming extensive today especially in industry, and at stores and lodgings. Considering the features of actuators used in the design of each LED system, they have difference in terms of quality of power. In this sense, in the study experimental LED loads for LED bulbs, LED projectors, downlights, and panel type LED systems were used. The testing mechanisms of the LED loads used are shown in Figure 24.

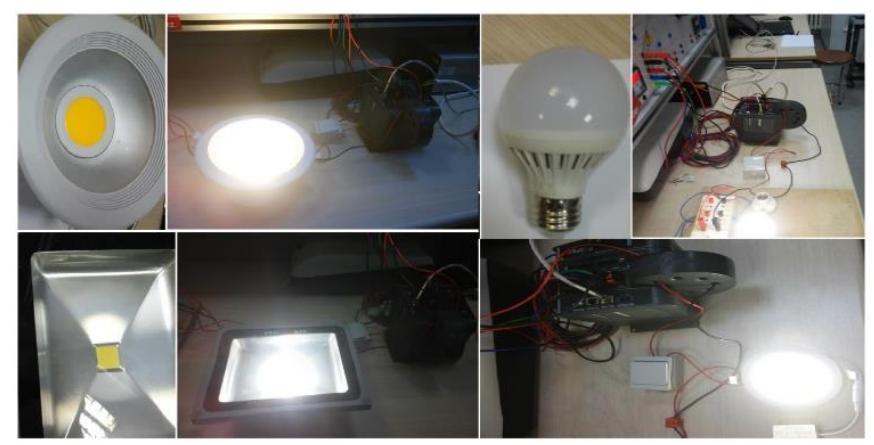

Figure 24. Testing mechanisms for LED lamps

In the experiments performed, it was observed that the LED lamps didn't cause voltage and current waves in the network they were connected. But considering that the actuators used were non-linear, significant differences in the PF values and harmonic values of the network were in subject.

If we examine the LED loads respectively, values of current, voltage and PF measured on the network in terms of quality of 
power for different LED loads are indicated in Figures 25, 26, and 27.

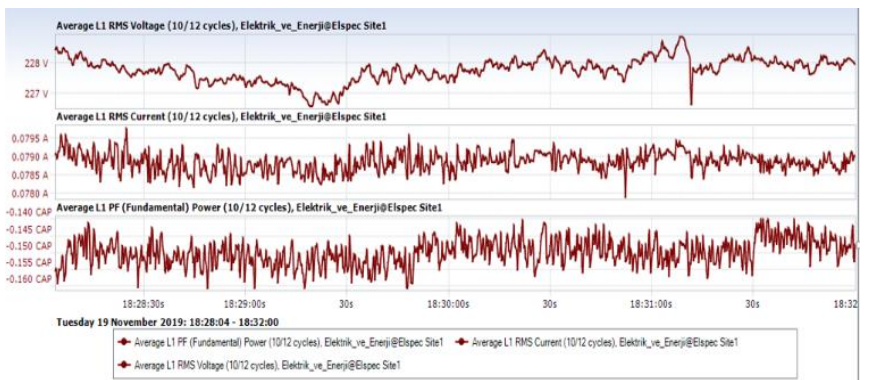

Figure 25. Values of RMS voltage, RMS current, and replacement PF of LED bulb (4 W) during measurement

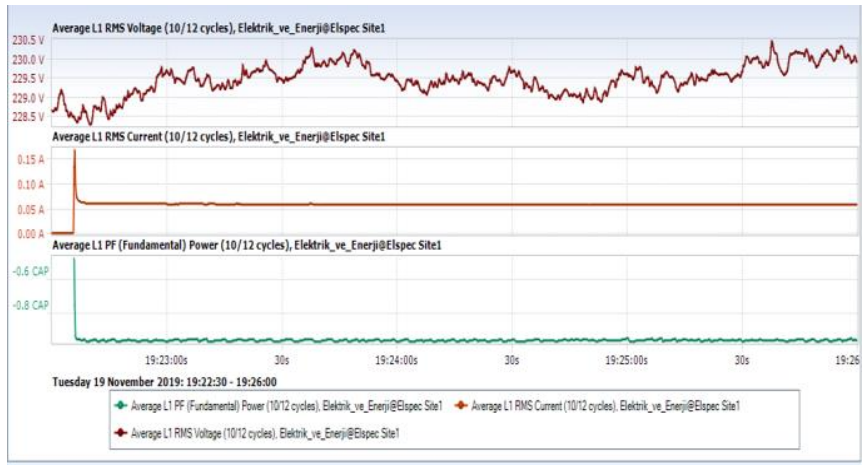

Figure 26. Values of RMS voltage, RMS current, and replacement PF of LED Slim Panel (6 W) Luminaire during measurement

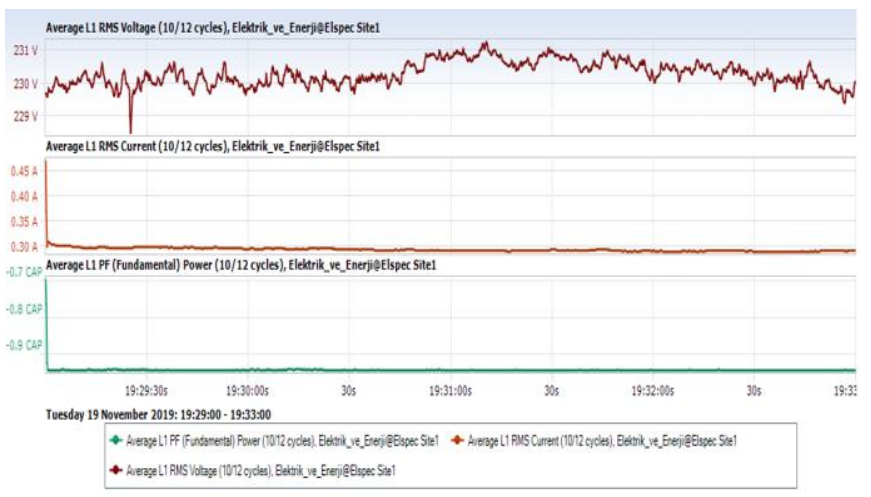

Figure 27. Values of RMS voltage, RMS current, and replacement PF of LED Projector $(50 \mathrm{~W})$ Luminaire during measurement

As observed in the above figures, the LED systems cause a nonlinear capacitive load state, and the PF values rise much above the value of 1 despite lack of formation of current and voltage fluctuations on the network. Moreover, distortions in the current waveforms of these systems were in subject, and in terms of $\%$ THD, current harmonics were observed in the environment.

As clearly observed on graphs in Figures 28, 29, and 30, even if the LED loads are being preferred as efficient light sources today, they are able to highly distort the quality of power due to their non-linear characteristics, and they are harmonic light sources which can reach to $100 \%$ THD values.

These systems don't form current waves on the network, and the value of crest factor is able to a bit higher than $\sqrt{2}$. In Figure 31 , graphs of different loads are present.

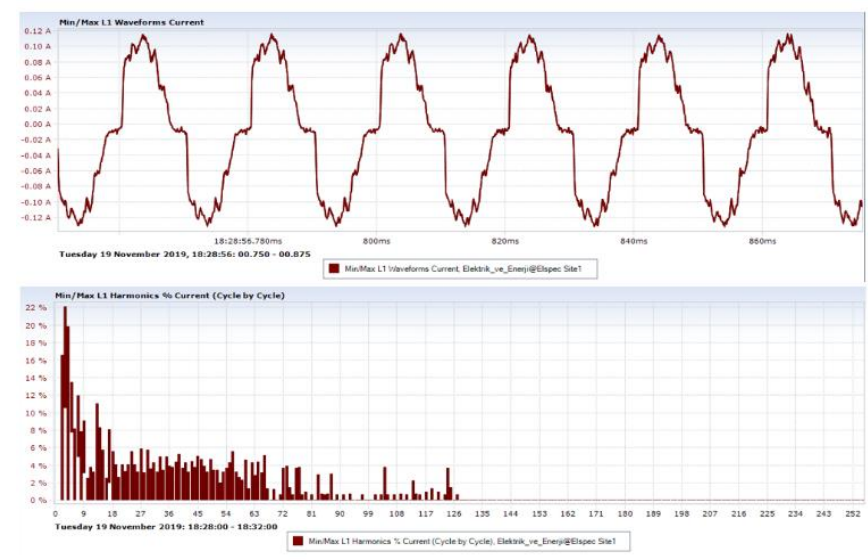

Figure 28. Current harmonics (\% THD), and current waveform for a LED bulb (4 W)

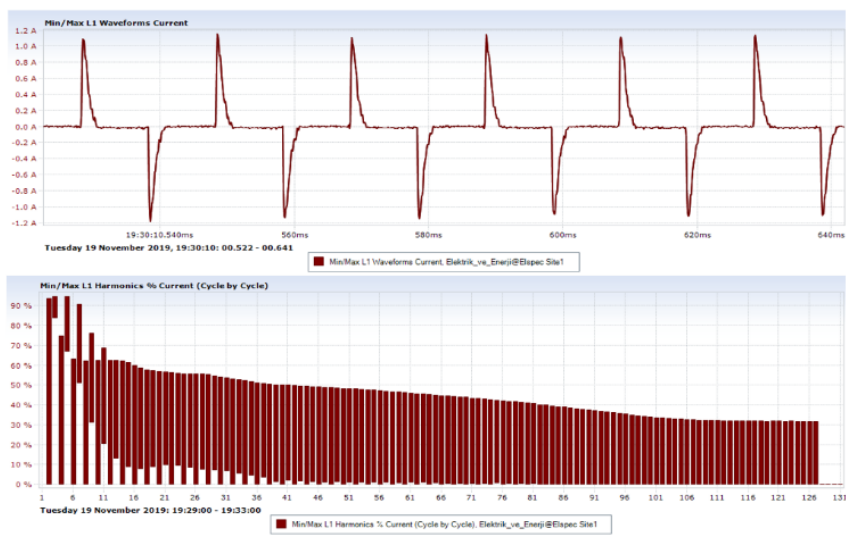

Figure 29. \% THD and current waveform of a magnetic LED Slim Panel (6 W) Luminaire
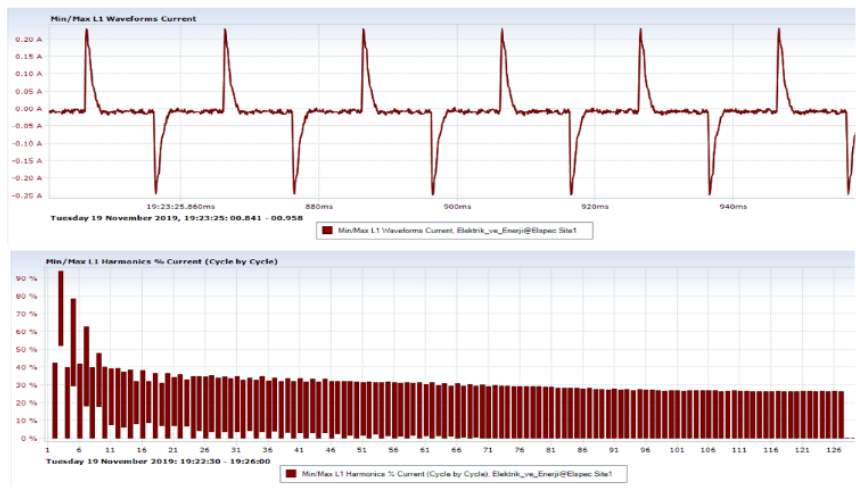

Figure 30. $\%$ THD and current waveform of a LED Projector $(50 \mathrm{~W})$ Luminaire

LED systems are very sensitive due to their construct. Sudden fluctuations which may arise on the network are able to damage the functions of these systems. For this reason, during switching performed for 1 minute, inrush currents were measured on these loads. In Figure 32, this state for LED bulb, LED panel, and LED projector was summarized. In Figure 32, inrush current graphs of 3 different LED loads are indicated. These are LED loads consuming $4 \mathrm{~W}, 6 \mathrm{~W}$, and $50 \mathrm{~W}$ power, respectively. In Figure 32, $4 \mathrm{~W}$ LED bulb at the top draws a current of $0.078 \mathrm{~A}$ from the network, but it forms an inrush current up to $5.9 \mathrm{~A}$. In the same manner, the one in the middle is the graph of inrush current of a $6 \mathrm{~W}$ LED panel type 
luminaire. Under normal conditions, this load demands $0.05 \mathrm{~A}$ current from the network, but it forms an inrush current of 26.24 A. And on the bottom graph in Figure 32, the LED projector load, which drawn a current of 0.29 A under normal conditions, forms an inrush current up to $75.52 \mathrm{~A}$. Due to the analyses performed, when the middle and bottom graphs in Figure 32 are examined, the inrush currents of these two loads are very high, and when the graphs in Figure 31 are examined, the crest factor values of these loads are high. Moreover, the current waveforms and harmonic spectrums in Figures 29 and 30 exhibit that these two loads are very high in harmonic sense. Therefore, by the analyses performed, the \% THD values of lighting sources, with high inrush current values and crest factor values, are being very high. Moreover, when the PF values of these loads were examined, it was observed that they had capacitive characteristics, and that they exceeded the value of $P F=1$, and that their $\cos \varphi$ values were not equal to the value of PF.

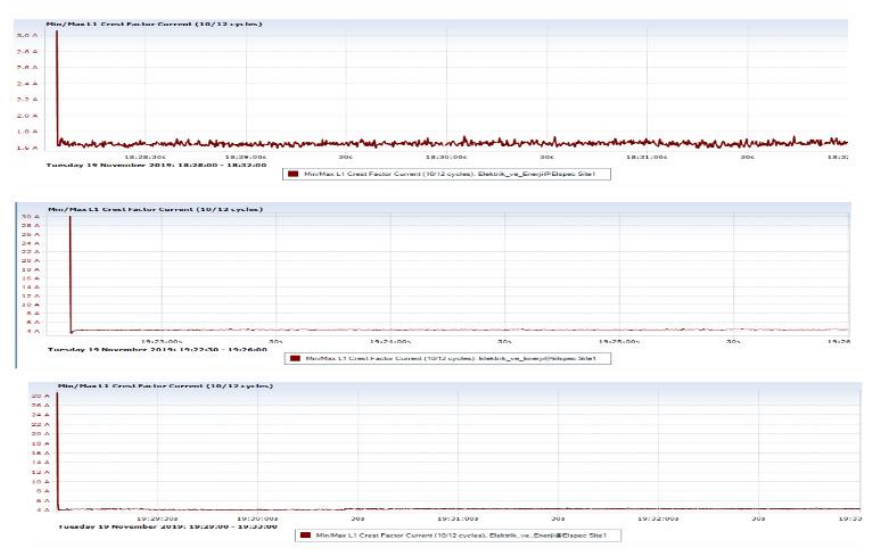

Figure 31. Graphs of crest factors of different LED loads (LED bulb at the top, LED panel in the middle, and LED projector at the bottom)

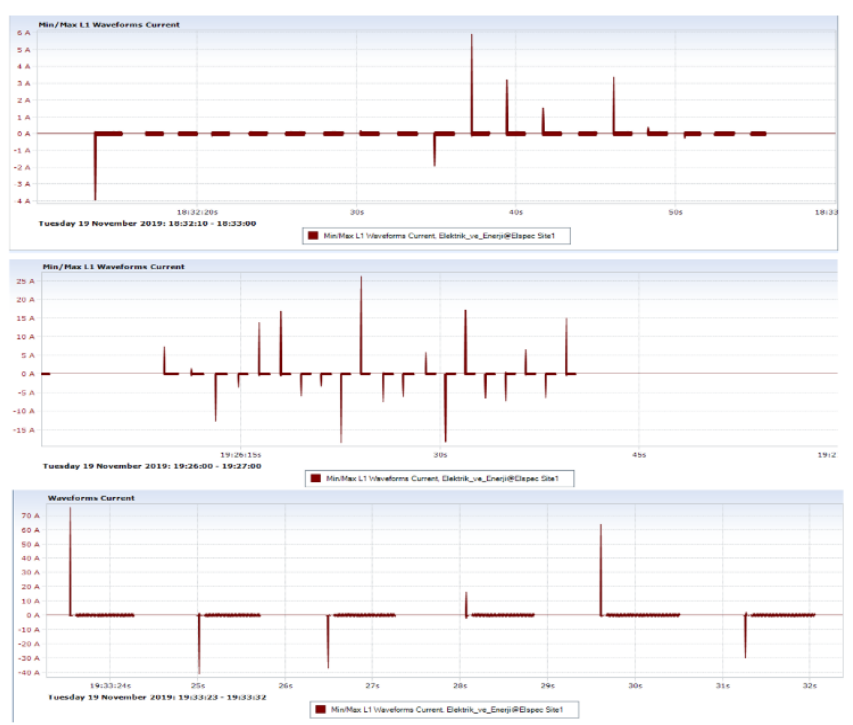

Figure 32. Graphs of temporal change of inrush currents obtained during switching for one minute of three different LED laps (LED bulb at the top, LED panel in the middle, and LED projector at the bottom)

In Table 4, as the result of the experimental measurements performed, the effects on the network of lighting sources used are indicated as not present (-), and present (+). As observed in Table 4, as the lighting devices don't form voltage fluctuations, voltage drops, overvoltage, imbalance and notch, some laps and LED lamps operating as per the principle of gas discharge are able to be affected from inrush currents arising by the instantaneous voltage fluctuations on the network itself. The main reason of this is the inferiority of the actuator and ballast sourced systems where they are used, and as a result difference of power factor values from the $\cos \varphi$ values, and formation of excessive harmonics on the system.

TABLE 4

NEGATIVE EFFECTS ON THE NETWORK OF LIGHTING ELEMENTS USED IN EXPERIMENTAL ANALYSES

\begin{tabular}{|c|c|c|c|c|c|c|c|c|c|}
\hline Lighting Elements Used & $\begin{array}{l}\text { Voltage } \\
\text { Drop }\end{array}$ & $\begin{array}{c}\text { Voltage } \\
\text { Fluctuations }\end{array}$ & Overvoltage & Harmonics & Imbalance & $\begin{array}{l}\text { Inrush } \\
\text { Current }\end{array}$ & $\begin{array}{c}\text { Crest } \\
\text { Factor } \\
<\sqrt{2}\end{array}$ & Notch & $\begin{array}{l}\text { Flicker } \\
\text { Effect }\end{array}$ \\
\hline LED Bulb & - & - & - & + & - & + & + & - & + \\
\hline Halogen Glow Bulb & - & - & - & - & - & + & + & - & - \\
\hline LED 15W Bulb & - & - & - & + & - & + & + & - & - \\
\hline Compact_Key_30 W & - & - & - & + & - & + & + & - & - \\
\hline Compact_wanlee_32 W & - & - & - & + & - & + & + & - & - \\
\hline Compact_Osram_32 W & - & - & - & + & - & + & + & - & - \\
\hline SlimLEDPanel_hliteDriver_6 W & - & - & - & + & - & + & + & - & + \\
\hline LEDProjector_50 W & - & - & - & + & - & + & + & - & + \\
\hline LED Downlight_AcUltralight & - & - & - & + & - & + & - & - & - \\
\hline $\begin{array}{l}\text { Road Lighting_Mercury_E27_70 } \\
\text { W }\end{array}$ & - & - & - & + & - & + & + & - & - \\
\hline $\begin{array}{l}\text { Road } \\
\text { Lighting_Mercury_E40_Philips150 }\end{array}$ & - & - & - & + & - & + & + & - & - \\
\hline $\begin{array}{l}\text { Road } \\
\text { Lighting_Sodium_E40_HST150 W }\end{array}$ & - & - & - & + & - & + & + & - & - \\
\hline Fluorescent_2x36 W & - & - & - & - & - & + & + & - & - \\
\hline
\end{tabular}


In Table 5, the results of measurements of all the loads used in the analyses performed are shown. Moreover, considering especially the operation characteristics of LED and gas discharge lamps by the use of external non-linear driver/ballast units on these light sources, the effects of lighting elements on quality of power are examined as sub-articles.

All the lighting devices used in the experiments form inrush currents during initial switching, and relevant instant switching power losses. But depending on the type and power of the lamp, and on the quality of actuator on which it is used, inrush currents' amplitude values and their ratios to nominal currents varied. Even if the inrush currents of mercury and sodium vapor luminaires used for road lighting were high by being about $75.58 \mathrm{~A}$, this rate is being about 75 times by drawing of about 1 A current, and it is low compared to other LED lamps. But especially in $6 \mathrm{~W}$ LED Slim, and $50 \mathrm{~W}$ Projector Luminaires with $100 \%$ THD level, the inrush currents were measured as 26.24 A and 75.52 A, respectively. These lamps normally drew $0.057 \mathrm{~A}$ and $0.291 \mathrm{~A}$ current from the network, respectively. Considering this circumstance, this type of LED systems are very sensitive loads in terms of their functions. For instance, as the ratios of inrush currents of these 2 types of LED lamps to their current drawn from the network were 460 times and 259 times respectively, it was found as very high compared

TABLE 5

RESULT OF EXPERIMENTAL MEASUREMENTS OF LIGHTING ELEMENTS USED IN THE ANALYSIS

\begin{tabular}{|c|c|c|c|c|c|c|c|c|c|}
\hline Bulb Types & $\begin{array}{c}\text { Experiment } \\
\text { Voltage's } \\
\text { Average } \\
\text { (RMS) } \\
\text { Value } \\
\text { (Volt) }\end{array}$ & $\begin{array}{c}\text { Average } \\
\text { Current } \\
\text { Drawn } \\
\text { from the } \\
\text { System } \\
\text { (Ampere) }\end{array}$ & $\begin{array}{c}\text { Max. } \\
\text { Inrush } \\
\text { Current } \\
\text { (Ampere) }\end{array}$ & $\begin{array}{c}\text { Total } \\
\text { Harmonic } \\
\text { Distortion } \\
\text { of Load } \\
\text { Current } \\
\text { Drawn } \\
\text { from the } \\
\text { Network, } \\
\text { average } \\
\text { \% THD } \\
\end{array}$ & $\begin{array}{c}\text { Crest } \\
\text { Factor } \\
\text { Current, } \\
\text { average }\end{array}$ & $\begin{array}{c}\text { Power } \\
\text { Values } \\
\text { Drawn from } \\
\text { the System } \\
\text { (average W, } \\
\text { VAr, VA) }\end{array}$ & $\begin{array}{r}\text { Funda } \\
\text { Po } \\
\text { Fac } \\
\text { (Co }\end{array}$ & $\begin{array}{l}\text { nental } \\
\text { er } \\
\text { tor } \\
\varphi)\end{array}$ & $\begin{array}{c}\text { True Power } \\
\text { Factor (PF) } \\
\text { Fundamental } \\
+ \text { Harmonics }\end{array}$ \\
\hline LED Bulb & 7 & $0.078 \mathrm{~A}$ & $5.9 \mathrm{~A}$ & $22 \%$ & $1.64 \mathrm{~A}$ & $\begin{array}{c}2.6 \mathrm{~W} ;- \\
\text { 17.49VAr; } \\
17.68 \mathrm{VA}\end{array}$ & -0.14 & cap & -0.14 cap \\
\hline Halogen Bulb & $\begin{array}{l}227.83 \mathrm{~V} \\
\mathrm{AC}\end{array}$ & $0.127 \mathrm{~A}$ & $0.8 \mathrm{~A}$ & $1.90 \%$ & $1.46 \mathrm{~A}$ & $\begin{array}{l}29 \mathrm{~W} ;- \\
0.62 \mathrm{VAr} ; \\
29.04 \mathrm{VA}\end{array}$ & 0.99 & ind & 0.99 ind \\
\hline LED 15 W Bulb & $\begin{array}{l}228.49 \mathrm{~V} \\
\mathrm{AC}\end{array}$ & $0.065 \mathrm{~A}$ & $0.09 \mathrm{~A}$ & $19.65 \%$ & $1.58 \mathrm{~A}$ & $\begin{array}{c}14.31 \mathrm{~W} ;- \\
4.11 \mathrm{VAr} ; \\
14.89 \mathrm{VA}\end{array}$ & -0.97 & cap & -0.96 cap \\
\hline Compact_key_30 W_bulb & $\begin{array}{l}229.33 \mathrm{~V} \\
\mathrm{AC}\end{array}$ & $0.143 \mathrm{~A}$ & $12.22 \mathrm{~A}$ & $87.83 \%$ & $3.1 \mathrm{~A}$ & $\begin{array}{c}21.74 \mathrm{~W} ; \\
24.72 \mathrm{VAr} ; \\
32.93 \mathrm{VA}\end{array}$ & -0.88 & cap & -0.66 cap \\
\hline Compact_wanlee_32 W_bulb & $\begin{array}{c}228.76 \mathrm{~V} \\
\mathrm{AC}\end{array}$ & $0.121 \mathrm{~A}$ & $12.74 \mathrm{~A}$ & $99.99 \%$ & $3.08 \mathrm{~A}$ & $\begin{array}{l}17.09 \mathrm{~W} ;- \\
21.30 \mathrm{VAr} ; \\
27.31 \mathrm{VA}\end{array}$ & -0.91 & cap & -0.62 cap \\
\hline Compact_osram_24 W_bulb & $\begin{array}{l}228.87 \mathrm{~V} \\
\mathrm{AC}\end{array}$ & $0.112 \mathrm{~A}$ & $8.17 \mathrm{~A}$ & $99.24 \%$ & $2.98 \mathrm{~A}$ & $\begin{array}{c}16.91 \mathrm{~W} ;- \\
19.98 \mathrm{VAr} ; \\
26.18 \mathrm{VA}\end{array}$ & -0.91 & cap & -0.64 cap \\
\hline LEDSlimPanel_hliteDriver_6W_bulb & $\begin{array}{l}229.47 \mathrm{~V} \\
\mathrm{AC}\end{array}$ & $0.057 \mathrm{~A}$ & $26.24 \mathrm{~A}$ & $100 \%$ & $4.3 \mathrm{~A}$ & $\begin{array}{c}6.6 \mathrm{~W} ;- \\
11.26 \mathrm{VAr} ; \\
13.06 \mathrm{VA}\end{array}$ & -0.95 & cap & -0.5 cap \\
\hline LED Projector_50 W_bulb & $\begin{array}{l}230.27 \mathrm{~V} \\
\mathrm{AC}\end{array}$ & $0.291 \mathrm{~A}$ & $75.52 \mathrm{~A}$ & $100 \%$ & $4.23 \mathrm{~A}$ & $\begin{array}{c}34.19 \mathrm{~W} ;- \\
\text { 57.99VAr ; } \\
67.33 \mathrm{VA}\end{array}$ & -0.94 & cap & -0.5 cap \\
\hline LED Downlight_AcUltralight_bulb & $\begin{array}{l}229.63 \mathrm{~A} \\
\mathrm{AC}\end{array}$ & $0.150 \mathrm{~A}$ & $3.39 \mathrm{~A}$ & $20 \%$ & $1.38 \mathrm{~A}$ & $\begin{array}{l}33.05 \mathrm{~W} ;- \\
9.98 \mathrm{VAr} ; \\
34.54 \mathrm{VA}\end{array}$ & -0.97 & cap & -0.95 cap \\
\hline Road Lighting_Mercury_E27_70W & $\begin{array}{l}229.18 \mathrm{~V} \\
\mathrm{AC}\end{array}$ & $0.394 \mathrm{~A}$ & $36.75 \mathrm{~A}$ & $24.24 \%$ & $1.71 \mathrm{~A}$ & $\begin{array}{c}\text { 71.35W } \\
\text { 48.37VAr } \\
\text { 90.52VA }\end{array}$ & 0.85 & ind & 0.82 ind \\
\hline $\begin{array}{l}\text { Road } \\
\text { Lighting_Mercury_E40_Philips150W }\end{array}$ & $\begin{array}{l}230.13 \mathrm{~V} \\
\mathrm{AC}\end{array}$ & $0.984 \mathrm{~A}$ & $75.55 \mathrm{~A}$ & $29.84 \%$ & $1.82 \mathrm{~A}$ & $\begin{array}{c}125.40 \mathrm{~W} \\
172.45 \mathrm{VAr} \\
220.75 \mathrm{VA}\end{array}$ & 0.94 & ind & 0.91 ind \\
\hline $\begin{array}{l}\text { Road Lighting_Sodium_E40_HST } \\
150 \mathrm{~W}\end{array}$ & $\begin{array}{l}229.63 \mathrm{~V} \\
\mathrm{AC}\end{array}$ & $0.964 \mathrm{~A}$ & $75.58 \mathrm{~A}$ & $30.36 \%$ & $1.85 \mathrm{~A}$ & $\begin{array}{c}108.88 \mathrm{~W} \\
170.08 \mathrm{VAr} \\
206.82 \mathrm{VA}\end{array}$ & 0.88 & ind & 0.88 ind \\
\hline Fluorescent_2x36 W & $\begin{array}{c}230.52 \mathrm{~V} \\
\mathrm{AC}\end{array}$ & $0.911 \mathrm{~A}$ & $4.253 \mathrm{~A}$ & $9.65 \%$ & $1.53 \mathrm{~A}$ & $\begin{array}{c}\text { 91.12W ; } \\
\text { 182.077VAr; } \\
\text { 203.75VA }\end{array}$ & -0.90 & cap & -0.44 cap \\
\hline
\end{tabular}


to road lighting devices. Thus, when a decision is being made for the use of LED lighting devices especially at enterprises, the sources with low THD values should be selected. In the experiments performed, it was observed that both the inrush currents of the LED sources with low harmonic levels, and the ratio of their inrush currents to nominal current were low. Moreover, as they are highly used at enterprises or factories as these systems are capacitive, they have significant negative effects of electricity demand, and for this reason, it is required to use compensation units at enterprises where such lighting elements are being used. In these lighting devices, with high harmonic values, the values of crest factor are also much above the normal by being 3-4 times higher.

\section{CONCLUSION}

While selecting lighting lamps, it is important to consider the circumstances which may create negativities such as harmonics, power factor, crest factor, inrush current, and flicker effect in terms of quality of power. In our study, the quality of power of lighting elements with glow filament, of lighting elements of discharge group, and of lighting elements of LED group was examined in detail. The findings obtained indicated significant negativities in terms of quality of power in all the lamps except halogen glow lamps in terms of their effects on the network despite not observing any notches on all the lamps. When these negativities are addressed individually as PF, harmonics, inrush currents, and crest factor, the PF values are at low values especially in LED lamp and fluorescent lamp luminaires, and they are able to form significant harmonics on the network as capacitive loads. And especially the PF values of some $30 \mathrm{~W}$ and $32 \mathrm{~W}$ compact fluorescent lamps, lower power $6 \mathrm{~W}$ LED slim panels, and $50 \mathrm{~W}$ projectors have 0.5-0.6 capacitive values, and they are far from the value of $\cos \varphi$, and it was observed that they form significant current harmonics at the range of $87-100 \%$ THD. In the direction of these analyses, while using devices which can reach to high lighting amounts along with low power consumption in terms energy efficiency, their quality of power should be additionally considered in terms of their effects on the network, their lifetime, and the safety of environment. Especially by the extension of the use of LED systems today, in the process of decision making for use of numerous lighting sources at outer lightings, at road lightings, and at large enterprises, the negative effects on the network and on the users shouldn't be ignored. For this reason, in all the lighting lamps, the lighting sources with a THD rate below $10 \%$ should be preferred, and it shouldn't be ignored that the PF values may be above 1 by the use of numerous such lighting sources, and advanced compensation units should be additionally used.

\section{ACKNOWLEDGEMENT}

Authors would like to thank late Assistant Professor Doctor Selçuk Atiş from Vocational School of Technical Sciences of University of Marmara for his tremendous effort and valuable contribution.

\section{REFERENCES}

[1] N. Luewarasirikula, "A Study of Electrical Energy Saving in Office," Procedia - Social and Behavioral Sciences, vol. 197, pp. 1203 - 1208,
2015.W.-K. Chen, Linear Networks and Systems. Belmont, CA, USA: Wadsworth, 1993, pp. 123-135.

[2] P. O. Oluseyi, T. E. Somefun, O. M. Babatunde, T.O. Akinbulire, O. Oluleke, O. O. Babayomi, A. Samuel, S. A. Isaac, D. E. Babatunde, "Evaluation of Energy-efficiency in Lighting Systems for Public Buildings," International Journal of Energy Economics and Policy, vol. 10, pp. 435-439, 2020.

[3] K. Khaled Bataineh, A. Alrabee, "Improving the Energy Efficiency of the Residential Buildings in Jordan," Buildings 2018, 8, 85; doi:10.3390/buildings8070085.

[4] A. Balaras, Constantinos., G. A. Gaigla, E. Georgopoulou, S. Mirasgedis, Y. Sarafidis, P. D. Lalas, "European Residential Buildings and Empirical Assessment of The Hellenic Building Stock, Energy, Building and Environment," vol. 42, Issue 3, pp. 1298-1314, 2007

[5] B. Mills, J. Schleich, "Household transitions to energy efficient lighting," Energy Economics, vol. 46, pp. 151-160, 2014.

[6] K. R. Wagiman, M.N. Abdullah, N. H. Mohammad Radzi, M. Y. Hassan, "Lighting system control techniques in commercial buildings: Current trends and future directions," Journal of Building Engineering 31:101342, 2020. doi:10.1016/j.jobe.2020.101342.

[7] S. R. Barrold, B. K. Patel "A thyristor reactive power compensatör for fast-Varrying industrial loads," International Journal of Electronics, vol.51, no.6, pp.763-767,198.

[8] P. Devanathan, "A survey of harmonic distortion and reduction techniques," International Journal of Pharmacy and Technology, , vol. 8, pp. 23581-23589, 2016.

[9] B. A. Adegboye, "Power Quality Assessment in a Distribution Network," Advanced Materials Research Vol. 62/64, pp. 53-59, 2009.

[10] A. Ozdemir, A. Ferikoglu, "Low cost mixed-signal microcontroller based power measurement technique," IEEE Proceedings-Science Measurement And Technology, vol.151, pp.253-258, 2004. doi: 10.1049/ip-smt:20040242 - JUL, WOS:000222969400004.

[11] S. Atış, U. K. Terzi, M. Onat, "Comparative Investigation of Effects of Inrush Currents on Switching Components of Energy Efficient Lighting Elements. The 6th European Conference On Renewable Energy Systems," 2018, Istanbul, Turkey

[12] "ABS Guidance Notes On Control Of Harmonics In Electrical Power Systems," American Bureau of Shipping Incorporated by Act of Legislature of the State of New York 1862, pp. 29-60, 2006.

[13] C. Venkatesh, D. S. Kumar, D. V. S. Sima Sarma, M. Sydulu, "Modelling of Nonlinear Loads and Estimation of Harmonics in Industrial Distribution System," Fifteenth National Power Systems Conference (NPSC), IIT Bombay, December 2008.

[14] W.M. Grady, S. Santosa, "Understanding power system harmonics," USA, pp. $37-44,2001$.

[15] J. Kumru Arrillaga, N. R. Watson, "Power System Harmonics," Lohn Wiley \&Sons,USA, 2003.

[16] P. J. Nelson, "A Beter Understanding of Harmonic Distortion in the Petrochemical Industry," IEEE Transactions on Industry Applications, vol. 40, pp. 220-231, 2002

[17] R. D. Henderson, J. Patrick, P. J. Rose, "Harmonics: The Effects on Power Quality and Transformers," IEEE Transactions on Industry on Industry App., vol. 30, pp. 528-532, 1994.

[18] S. J. B. Ong, Y. J. Cheng, "An overview of international harmonics standards and guidelines (IEEE, IEC, EN, ER and STC) for low voltage system," International Power Engineering Conference, 2007. IPEC 2007.

[19] IEC 61000-3-2, (2004), Electromagnetic compatibility (EMC) - Part 3 2: Limits - Limits for harmonic current emissions (equipment input current $\leq 16$ A per phase.

[20] D. C. Agrawal, H. Leff, "Efficiency and efficacy of incandescent lamps," American Journal of Physics, vol. 64, pp. 649-654, 1996, doi:10.1119/1.18260.

[21] P. Verma,, N. Patel, Nirmal-Kumar C. Nair, "CFL to LED Transition: An Analysis From Harmonics Perspective," IEEE International Conference on Power System Technology (POWERCON'16), 28 Sept.1 Oct., Wollongong, NSW, Australia.

[22] S. Singh, S. Bhullar, "Hardware implementation of auto switching and light intensity control of LED lamps", Balkan Journal of Electrical \& Computer Engineering, September 2016 Vol.4 No.2, pp.67-71

[23] B.Yuksel, I. Kiyak, "Thermal Circuit Calculation and Real-Time Analysis of Led Light Source Luminaires", European Journal of Technique (EJT), Vol 10, Number 2, 2020, pp.252-263.

\section{BIOGRAPHIES}

Sait Dursun was born in Van in 1983. He graduated from Marmara University Electrical Teaching Department in 2008 and Sakarya University Electrical- 
Electronics Engineering in 2017. Since 2015, he has been continuing his postgraduate education at Marmara University, Faculty of Technology, Department of Electrical and Electronics Engineering. He worked at TEDAŞ between 2014-2018 and at Eltek Electric between 2018-2020. His research interests include High Voltage, Lighting Systems and Renewable Energy Systems.

Umit K. Terzi was born at Zonguldak in 1968. He received his B.S. and MSc. degrees from Marmara University in 1989 and 1994, respectively. He received his $\mathrm{PhD}$ degree from Marmara University in 2000. Since 2013, he is working as Prof. Dr. for Electrical-Electronics Department of Technology Faculty of Marmara University, and Electrical Education Department of Technical Education Faculty where he is head of the department. His research interests include Electrical Machinery, Power Systems, Energy Transmission and Distribution, and Renewable Energy Systems.

Onur Akar was born at Giresun in 1981. He received his undergraduate, graduate and doctorate degrees from Marmara University in 2005, 2011 and 2020 , respectively. He worked as lecturer at Istanbul Gedik University between 2010-2020. In the period of 2012-2015, he served as the Head of the Electrical Program at Istanbul Gedik University. He is working at same university as Assistant Professor Dr. in the Electricity and Energy Department, and as the Head of the Department of Electricity and Energy since 2021. His research interests include Control Systems, Renewable Energy Systems, Power Systems, and Lighting Systems.

Temel Sonmezocak was born in Edirne in 1978. He received his B.S. degree from Marmara University in 2001. In 2015, he completed his M.Sc. degree at Istanbul Aydin University, Department of Electrical and Electronics Engineering. In 2016, he started his Ph.D. program in Electronics Engineering at Ylldiz Technical University, and he is still continuing the same program. Since 2018, he is working as lecturer in Electrical Department of Istanbul Halic University. His research interests include Lighting Systems, Power Electronics, Algorithms, and Renewable Sources. 